\title{
The Polish-Catholic National Church: Between Messianism and Socialism
}

\author{
Jarosław Tomasiewicz \\ Institute of History \\ University of Silesia in Katowice \\ jaroslaw.tomasiewicz@us.edu.pl
}

\begin{abstract}
Religious reformism is sometimes linked with social radicalism. In Poland, perhaps the most striking example of this was Father Andrzej Huszno's Polish-Catholic National Church, which was active in the 1920's. The PKKN doctrine linked proletarian anti-capitalism and Polish national messianism of romantic provenance with an attempt to re-interpret Christianity in the theosophical spirit. This made Huszno's movement a tactical ally of the Piłsudkiites, who initially tried to maintain their social-radical and anticlerical traditions, and also make religious structures subordinate to the state (the Orthodox Church first in line). The Piłsudkiites' turn towards conservatism after the May Coup meant that the PKKN lost ground under its feet.
\end{abstract}

Keywords: messianism, theosophy, heterodoxy, reformism

Słowa kluczowe: mesjanizm, teozofia, heterodoksja, reformizm

Religious novelty is often associated with social reformism - and sometimes even political radicalism. A classic example of this is Father Andrzej Huszno, the founder of the Polsko-Katolicki Kościół Narodowy (the Polish-Catholic National Church $\mathrm{PKKN}$ ). Being a religious person, convinced of the value of religion and emotionally attached to it, he preached that " $[\mathrm{r}]$ eligion is a treasure of humanity, which we must defend, because, believing in progress and the rebirth of humanity, we believe that this can only happen on religious ground." It was supposed to be a religion based on love not only for God but also - and perhaps above all - for people. ${ }^{2}$ This put Huszno in

\footnotetext{
${ }^{1}$ A. Huszno, Kościót demokratyczny [The Democratic Church], Kraków 1919, p. 11.

2 Ibidem, p. 17.
} 
conflict with Roman Catholicism, which he accused of "idolatry" and "fetishism."" A logical consequence was questioning the Pope's authority and the whole organisation of the Church, which, according to Huszno, was characterised by despotism (he went so far as to compare the Pope to the "Russian Tsar or the Prussian Kaiser"). ${ }^{4}$ A no less serious sin was the cosmopolitanism of Roman Catholicism, generating an intractable conflict between the interests of the Vatican and those of the Polish nation. ${ }^{5}$ At the same time, the Church was criticised for indifference to the poor and favouring the rich: "Woe to you priests, who [...] have become guardians and worshippers of the golden calf, capital." "Finally, he reproached the Roman Catholic clergy for their materialism and greed, "drunkenness and lewd orgies," and common crimes. ${ }^{7}$

However, other Christian denominations, even those that were close to his own, met with reluctance on the part of Huszno. ${ }^{8}$ The main opponent of the PKKN - after the Roman Catholic Church - was the similarly named Polski Narodowy Kościól Katolicki (Polish National Catholic Church - PNKK), which he classified as "liberalising American Protestantism," replacing dogmatism with "gross rationalism." 10 Huszno accused the PNKK of approving of the theory of evolution and of consider-

${ }^{3}$ W. Nałęcz, Wieści z Babilonu [News from Babylon], "Głos Ziemowida" [henceforth: GZ] 1925, no. 20. [Note: an abbreviated form of footnote is not applied in relation to titles of articles from "Głos Ziemowida," due to their frequent similarity or even identicalness].

${ }^{4}$ A. Huszno, Polski Kościót Narodowy, jego historja, cel i zasady [The Polish National Church, its History, Goal and Principles], Dąbrowa Górnicza 1928, p. 1; cf. e.g. W. Wójcik, List z Brazylji [Letter from Brazil], GZ 1925, no. 23.

${ }^{5}$ As "Głos Ziemowida," wrote - anticipating Jan Stachniuk’s later criticism of Catholicism - "In the 16th century, the Jesuits transformed Poland into a cosmopolitan country." S. Mieczysław, Czasy sie powtarzaja [Times repeat themselves], GZ 1925, no. 18; cf. J. Tomasiewicz, Religia, naród i państwo w neopogańskiej filozofii Jana Stachniuka [Religion, Nation and State in the Neo-Pagan Philosophy of Jan Stachniuk], "Nomos" 1999, no. 24-25. See also A. Huszno, Polski Kościót Narodowy..., op. cit., p. 28; Unarodowienie Kościoła Rzymskiego w Polsce [Nationalising of the Roman Catholic Church in Poland], GZ 1925, no. 18; Wieści z Babilonu, GZ 1925, no. 23; W. Nałęcz, Wieści z Babilonu, GZ 1925, no. 24.

${ }^{6}$ Robotniku, w Bogu cata nadzieja twoja! [Worker, All Your Hope Lies in God!], GZ 1925, no. 6; also Kościót a kwestja społeczna [The Church and Social Issues], GZ 1924, no. 2; W.N., W sprawie bezrobotnych i zredukowanych [On the Unemployed and Dismissed], GZ 1925, no. 13; W. Nowak, Co oni z nauka Chrystusa zrobili? [What have They Done with the Teachings of Christ?], GZ 1925, no. 18.

7 W.N., Odpowiedź księdzu Ziemniakowi [Reply to Father Ziemniak], GZ 1925, no. 15; Wieści z Babilonu, GZ 1925, no. 16; Wieści z Babilonu, GZ 1925, no. 23; W. Nałęcz, Wieści z Babilonu, GZ 1925, no. 24. The only Roman Catholic priest about whom "Głos Ziemowida" spoke positively was Father Wacław Bliziński, due to his social activity. Jeden wśród sześciu tysięcy [One amongst six thousand], GZ 1925, no. 13.

${ }^{8}$ Although at the same time he appealed for non-aggression and a gradual rapprochment between Polish "national" Churches. A. Huszno, Pod hastem zjednoczenia [Under the banner of unity], GZ 1925, no. 6. Among the few groups that were positively rated was the esoteric Bractwo Odrodzenia Narodowego (Brotherhood of National Revival - BON). A. Huszno, Bractwo odrodzenia [Brotherhood of Revival], GZ 1925, no. 24. For more on the BON, see J. Tomasiewicz, Naprawa czy zniszczenie demokracji? Tendencje autorytarne i profaszystowskie w polskiej myśli politycznej (1921-1935) [Repair or destruction of democracy? Authoritarian and pro-fascist tendencies in Polish political thought (1921-1935)], Katowice 2012, pp. 353-357.

${ }^{9}$ Z obozu Narodowców amerykańskich [From the American National-Catholic camp], GZ 1925, no. 15 .

${ }^{10}$ A. Huszno, Polski Kościót Narodowy..., op. cit., p. 13. 
ing the Holy Scripture as a record of beliefs without a hidden meaning, which led them to view Christ as a reformer of Judaism and to treat church ceremonies as remnants of fetishism. " "They consider Christ an ordinary mortal, but they worship Him in the Eucharist, just so as not to frighten people away from themselves," he wrote. ${ }^{12}$ In addition, according to Huszno, the PNKK lacked a significantly Polish national character, since it was based on "Judeo-Roman [...] foundations."13 Huszno evaluated other denominations similarly. He accused followers of the Old Catholic Church of "hakatyzm" (subscribing to the chauvinist ideology of the German Eastern Marches Society), reproached the Mariavites for a "mysticism that is incomprehensible to mere mortals," and considered Protestantism as a "direction [...] rejecting tradition, and mysticism, and alien to the Slavic soul." 14

\section{Huszno's Church}

All these factors caused Huszno to set up his own Church. A vision had been germinating in the mind of the rebellious priest since 1917. It was then that he drew up his comprehensive plan for reorganisation of the Roman Catholic Church on democratic principles. The Church was to be based on a dualistic representation - created at the grassroots from both laity and clergy. Citizens representing the faithful were to choose parish councils, which would not only deal with financial matters, education and charity, but would also present a candidate for parish priest or approve him. Priests were to choose deans in the deaneries and bishops in the dioceses, and they would be approved by councils - deanery and diocesan respectively (composed of representatives of lower level councils). The Patriarch and the national council would be selected at the state level, the latter deciding on, amongst other things, the liturgical language. The Pope was to stand at the head of a universal Church, with a "council of the peoples" at his side, which "abolishes and establishes church laws [...] [and] is an infallible judge together with the Pope as to principles of faith and morality. It chooses the Pope." A universal council, elected by the faithful of both genders, would constitute the supreme authority. ${ }^{15}$

In setting up his own Church in 1924, Huszno somewhat modified the principles presented several years earlier in the "Democratic Church." On the one hand, the PKKN was to be "the Church of the people" and not "of the priestly caste," 16 and set itself as an objective "reviving the conciliar-democratic principle in the Church." 17

${ }^{11}$ Bończak i jego Kościót [Bończak and his Church], GZ 1925, no. 4.

12 A. Huszno, Polski Kościół Narodowy..., op. cit., p. 13.

13 [A.] Huszno, Skąd nagle żądanie łaczności? [Whence the Sudden Demand for Contact?], GZ 1925, no. 9 .

14 A. Huszno, Polski Kościót Narodowy..., op. cit., p. 14. Huszno emphasised, for example, that, unlike the Protestants, the PKKN recognised the veneration of angels and saints. Kult aniołów $i$ świętych [Veneration of angels and saints], GZ 1925, no. 21.

15 Ibidem, pp. 12-15.

${ }^{16}$ Kościót a kwestja społeczna [The Church and Social Issues], GZ 1924, no. 2.

17 A. Huszno, Polski Kościół Narodowy..., op. cit., p. 24. 
On the other hand, its "visible head" was to be its founder, having the decisive vote in matters of faith, morality and Church discipline (after consulting the Synod); only his successors would be elected by a national council composed of bishops and lay and clerical delegates. ${ }^{18}$ As Huszno explained, the National Church has a "[m]onarchosynodal [...] system in matters of faith, morality and church discipline, and a democratic one in administrative and economic matters."19 "Legal-ecclesiastical independence [...] from Rome and all foreign powers" as well as lack of celibacy were also constitutive features of the new denomination. ${ }^{20}$ In the liturgical sphere, the PKKN basically kept the Catholic liturgy and ritual, ${ }^{21}$ since it was easier to reach the faithful through forms that were known to them. However, an important novelty was the introduction of the Polish language alongside Latin, ${ }^{22}$ since, it was proclaimed, "[p]rayer in an incomprehensible language befits only the deaf and dumb."23

The new cult grew dynamically. Huszno's parish, located on Narodowa Street, had 1485 members. ${ }^{24}$ According to the PKKN parish chronicle, 340 people participated in retreats in April 1925, whilst 1500 took part in the Resurrection (Easter Procession) during Holy Week, and 3500-4000 attended a solemn mass. ${ }^{25}$ Dynamic social activities (including opening a library) ${ }^{26}$ and publishing ventures (e.g. the brochure Posłannictwo Polski Dawnej i Współczesnej ["The Mission of Historical and Contemporary Poland"]) were undertaken. ${ }^{27}$ The popular Zagłębie ${ }^{28}$ preacher was

${ }^{18}$ Ibidem, p. 27. "The visible head" spoke on behalf of "the invisible head" of the Church, i.e. Christ. Glówne zasady Polsko-Katolickiego Kościoła Narodowego w Dąbrowie Górn[iczej] [The main principles of the Polish-Catholic National Church in Dąbrowa Górnicza], GZ 1925, no. 12.

${ }_{19}$ Główne zasady Polsko-Katolickiego Kościoła Narodowego w Dabrowie Górn[iczej], GZ 1925, no. 12. Przeglad Powszechny sneered that "Catholic-monarchic atavism had expressed itself in him." Sprawy Kościoła [Church issues], "Przegląd Powszechny" 1926, vol. 172, p. 115.

${ }^{20}$ Główne zasady Polsko-Katolickiego Kościoła Narodowego w Dąrowie Górn[iczej], GZ 1925, no. 12. The abolition of celibacy was linked to the conviction that "above all, holy, virtuous people [...] should have children." Huszno justified this by writing that "[s]exual life [...] sanctified by a sacramental union in no way lowers man in relation to God [...]. The Glory of God requires that people multiply." Fatszywa opinja co do czystości [A False Opinion as to Purity], GZ 1925, no. 11.

${ }^{21}$ Rezurekcja [Resurrection], GZ 1925, no. 10.

${ }^{22}$ Główne zasady Polsko-Katolickiego Kościoła Narodowego w Dąbrowie Górn[iczej], GZ 1925, no. 12; W. Wójcik, List z Brazylji, GZ 1925, no. 23.

${ }^{23}$ Slogan [in:] GZ 1925, no. 4.

${ }^{24}$ M. Skrudlik, Zamachy na Kościót Katolicki w Polsce [Attacks on the Catholic Church in Poland], Warsaw 1928, p. 15. A. Grześczyk, Z dziejów ludowej herezji-Polski Narodowy Kościót Katolicki [From the History of Popular (Folk) Heresy - the Polish National Catholic Church], "Ha!art" 2016, no. 1 gives a figure of 8,000 followers, but without quoting a source. Perhaps he based this figure on Bolesław Ciepiela's data, according to whom six PNKK parishes numbered 7,500 faithful in 1922. B. Ciepiela, Historia parafii Matki Bożej Nieustajacej Pomocy w Strzyżowicach [History of the Parish of Our Lady of Perpetual Help in Strzyżowice], http://strzyzowice.pl/index.php?name=Sections\&req=viewarticle\&artid $=28 \&$ page $=1$ [access: 19.02 .2007 ].

${ }^{25}$ Kronika parafjalna [The Parish Chronicle], GZ 1925, no. 12.

${ }^{26}$ Zawiadomienie dla Dąbrowy i okolic [Notification for Dąbrowa and Surroundings], GZ 1925, no. 13

${ }^{27}$ Nasze wydawnictwo [Our Publishing House], GZ 1925, no. 21.

${ }^{28}$ Zagłębie Dąbrowskie (the Dąbrowa Coalfields) - the industrial region in southwestern part of the Second Polish Republic. 
the inspiration for the fictional Father Kania in Juliusz Kaden-Bandrowski's novel Czarne skrzydta ("Black Wings" - its author was staying in Zagłębie at that time - in late 1923/early 1924). ${ }^{29}$ But there were also failures. The activities of the PKKN met with a counteroffensive by the Roman Catholic Church (e.g. distributors of "Głos Ziemowida" ["The Voice of Ziemowid"]) were attacked $)^{30}$ and there was police repression. ${ }^{31}$ The authorities refused to legalise Huszno's Church. ${ }^{32}$ Relations with other faith groups (even close ones, such as the PNKK) remained tense. ${ }^{33}$

As a result, Huszno decided to enter into a union with Polski Autokefaliczny Kościół Prawosławny (the Polish Autocephalous Orthodox Church - PAKP). On 1 July 1926, the PKKN (retaining its old name for internal use) was transformed into the autonomous Polsko-Narodowy Kościół Prawosławny (Obrządku Zachodniego) (Polish National Orthodox Church - PNKP) (Western Rite), with Huszno as its head. ${ }^{34}$ The Polish National Orthodox Church was supposed to operate only amongst the Polish population. The "Conditions of Unification" stated that the union was based on the common dogmas of Christianity from before the Eastern schism, recognised the Nicene-Constantinopolitan Creed, the seven sacraments (baptism, confirmation, penance, holy communion, priesthood (ordination), marriage, anointing with holy oil), communion in two forms, and oral and general confession. Only bishops had to remain celibate. At the same time, the PNKP had full autonomy guaranteed - not only administrative and economic, but also liturgical (it was supposed to use the Western liturgy with Polish as the ritual language) and doctrinal autonomy. The document reads: "It is not forbidden [...] to symbolically translate the Holy Scriptures, the Symbols of Faith, the sacraments and dogmas, provided such interpretations are not contradictory to the teachings of the Church Fathers," and the following is recognised: "The messianic mission of the Polish Nation in the work of unifying the Slav peoples, in accordance with the teachings of Polish national bards." ${ }^{35}$ Huszno was promised episcopal dignity and a place in the synod alongside Orthodox bishops. ${ }^{36}$

Zagłębie Dąbrowskie remained the bastion of the PNKP - there was a parish in Dąbrowa Górnicza with branches in Maczki and Jęzor. ${ }^{37}$ The PNKP expanded from Zagłębie - where, apart from Huszno, Leon Ostrowski and Jan Pietruszka were also active - to other parts of Poland. In 1927, a former Roman Catholic priest, Father

${ }^{29}$ G. Gazda, Dwudziestolecie międzywojenne. Stownik literatury polskiej [The Interwar Period. Dictionary of Polish Literature], Gdańsk 2008, pp. 40-41.

${ }^{30}$ Przygody ,Ziemowida” [The Adventures of “Ziemowid”], GZ 1925, no. 13.

31 A. Huszno, Polski Kościót Narodowy..., op. cit., p. 12.

32 Przedwczesna radość Babilonu [The Premature Joy of Babylon], GZ 1925, no. 10.

33 [A.] Huszno, Ską nagle żądanie tączności?, GZ 1925, no. 9; A. Huszno, Polski Kościót Narodowy..., op. cit., p. 14. Bishop Franciszek Bończak from the PNKK wrote that Huszno "by proclaiming fantastically mystical theories that had nothing in common with Christianity, was excluded from the National Church.” M. Skrudlik, Zamachy..., op. cit., p. 11.

${ }^{34}$ A. Huszno, Polski Kościót Narodowy..., op. cit., pp. 15, 17.

${ }^{35}$ Warunki zjednoczenia Polsko-Katolickiego Kościoła Narodowego z Kościołem Polskim Prawostawnym [Conditions for the Unification of the Polish-Catholic National Church with the Polish Orthodox Church], "Jednodniówka Maryawicka" 1926, no. 8.

${ }^{36}$ Sprawy Kościoła, "Przegląd Powszechny” [“Universal Review”] 1926, vol. 172, p. 117.

37 A. Huszno, Polski Kościót Narodowy..., op. cit., p. 22. 
Stanisław Zacharjasiewicz, was supposed to organise a parish in Warsaw, in which Father Apolinary Filarski (formerly of the PNKK) also ministered. Father Bronisław Jaeger attempted to found a parish in Łódź, but he encountered resistance from the Orthodox community. ${ }^{38}$ In Bydgoszcz, a 40-person group from the PNKK led by Father Władysław Kocyłowski ${ }^{39}$ joined the ranks of the PNKP. PNKP adherents could also be found in Lublin (Father Andrzej Koszowski) ${ }^{40}$ and Siedlce (P.B. Komorowski). ${ }^{41}$ However, only the parishes in Dąbrowa Górnicza and Warsaw achieved legal status (9 October 1927). The Polish-National Orthodox Church gained the support of deputies from the left-wing Stronnictwo Chłopskie (the Peasant Party) - Józef Berk and Marcin Socha. The periodical "Polski Kościół Narodowy" ("Polish National Church"), published in place of "Głos Ziemowida," became the organ of the new denomination. ${ }^{42}$

The establishment of the PNKP was an unprecedented event. As Jan Mirończuk noted, "it was a rather rare example in history of a church union where the Eastern Church was to play the dominant role."43 The Jesuit periodical "Przegląd Powszechny" ("Universal Review") in turn drew attention to the departure of the Orthodox from identification of faith with rite. ${ }^{44}$ It would seem that the motive for entering into a union was, on the part of the National Church, the desire to avoid obstacles to the legalisation of the denomination (as Huszno wrote: "on our part, it is not a conversion to Orthodoxy, but the carrying out of legalisation under the name of the Polski Autokefaliczny Kościół Prawosławny"), ${ }^{45}$ whilst from the point of view of the Orthodox, it was a symmetrical response to the creation by Rome of the Byzantine Rite. ${ }^{46}$ However, the Union may have had another - political - basis. In a letter addressed to clerics of the PNKK, encouraging them to join with the PNKP, Huszno assured them that he had unofficial support from the Ministry of Religious Belief and Public

38 A. Huszno, Polski Kościól Narodowy..., op. cit., pp. 18, 20, 23. K. Chylak, Polski Narodowy Kościót Katolicki w Łodzi (1918-1951) [The Polish National Catholic Church in Łódź (1918-1951)], "Rocznik Łódzki" 2010, vol. LVII. The author gives the wrong name: Zachariewicz.

39 S. Pastuszewski, Karta prawosławna w dziejach Bydgoszczy [The Orthodox Chapter in the History of Bydgoszcz] [in:] Kalendarz Bydgoski na Rok 1987 [Bydgoszcz Calendar 1987], Bydgoszcz 1986, p. 32 .

40 A. Huszno, Polski Kościót Narodowy..., op. cit., p. 24. It seems that Koszowski had already cooperated with Huszno, but in June 1924, he went over to the PNKK. Bończak i jego Kościól [Bończak and his Church], GZ 1925, no. 4.

${ }^{41}$ M. Skrudlik, Zamachy..., op. cit., p. 105. See also Banda wyrzutków tworzy „,kościól polskoprawosławny”. Zza kulis sekciarstwa [A Band of Outcasts Creates "the Polish Orthodox Church". Behind the Scenes of Sectarianism], "Hasło Łódzkie" 1928, 4 January.

42 M. Skrudlik, Zamachy..., op. cit., pp. 16, 32, 39.

43 J. Mirończuk, Polski Narodowy Kościół Katolicki w Łomży - powstanie, oddziaływanie, zanik (1928-1944) [The Polish National Catholic Church in Łomża - establishment, influence, disappearance (1928-1944)], "Studia Łomżyńskie" 2009, vol. XX.

44 Sprawy Kościoła, "Przegląd Powszechny” 1926, vol. 172, p. 118.

45 M. Skrudlik, Zamachy..., op. cit., p. 35.

46 S. Jorsz, Historyczne znaczenie misji wschodniej jezuitów w Albertynie [The Historical Significance of the Eastern Mission of the Jesuits in Albertyna], "Roczniki Teologiczne" ["Theological Annals"] 2006-2007, vol. LIII-LIV (7). 
Enlightenment. ${ }^{47}$ This was not unrealistic. The sympathies of some Piłsudskiites ${ }^{48}$ (e.g. Tadeusz Hołówka) for the idea of a national Church are well-known, ${ }^{49}$ and at the same time they considered bringing the Orthodox Church under their control as being in the national interest ("The breaking up of the Orthodox Church in Poland is a state necessity," Z. Dreszer was to write in "Nowy Kurjer Polski"). ${ }^{50}$ Establishing the PNKP could have been an attempt to kill two birds with one stone, as Huszno himself admitted. According to "Przegląd Powszechny," "in his flights of fantasy $[\ldots]$ he reveals the perspective to Polish patriotism that bishops of this new Orthodoxy [...] will outnumber their Russian colleagues in the 'Holy Synod' in Warsaw."

Mutual suspicions (and also probably dashed hopes and ambitions on both sides) meant that relations between the PNKP and PAKP quickly reached a crisis. Not only was Huszno not appointed a bishop, but he did not even obtain a seat in the consistory of the Warsaw-Chełm diocese of the PAKP, which was taken by Zacharjasiewicz..$^{52} \mathrm{It}$ was not until 29 September 1927 that the General Administration of the PNKP was recognised, with Huszno, who received the title of infutat (mitred prelate), at its head. However, this caused another crisis - Zacharjasiewicz, Komorowski and Ostrowski left, with only Jaeger and Filarski remaining loyal to Huszno. ${ }^{53}$ The low quality of the recruited clergy in the Polish-Orthodox community bore rotten fruit. The author, who sympathised with Huszno, admits: "One of the co-workers, who was intoxicated by the prosperity in a Warsaw parish, became a bureaucrat rather than a pastor to his parishioners. [...] Another stopped working, as he had a weakness for alcohol and could not escape the addiction." 54

The PNKP survived until the Second World War, but it became completely marginalised. In 1931 and 1932, Huszno published the cultural-educational monthly "Kultura Ducha" ("Culture of the Soul"), but was severely affected by the death of his wife Stefania in July $1932 .{ }^{55} \mathrm{He}$ became more involved in herbalism and trading herbs than in pastoral care. At the end of his life in 1937, he took over the PNKP parish

47 M. Skrudlik, Zamachy..., op. cit., p. 35.

48 Followers of Józef Piłsudski, leader of the Polish Socialist Party (1895-1914), "the Commandant" of Polish Legions in World I, Chief of State (1918-1922), and de facto leader of the Second Polish Republic (1926-1935).

${ }^{49}$ I. Werschler, Z dziejów obozu belwederskiego. Tadeusz Hołówko - życie i działalność [From the History of the Belvedere Camp. Tadeusz Hołówko - Life and Activity], Warsaw 1984, pp. 303-306.

50 M. Skrudlik, Zamachy..., op. cit., pp. 19-20.

51 Sprawy Kościoła, "Przegląd Powszechny" 1926, vol. 172, p. 117. Interestingly, the National Democratic paper "Słowo Pomorskie" warned the Orthodox that "the fantasist, troublemaker and erotomaniac" Huszno [is] in the PNKP but is actually preaching his own doctrine that is contrary to the principles of the Orthodox Church. $Z$ tajemnic zbrodni marjawityzmu [From the Secrets of the Crimes of the Mariavites], "Słowo Pomorskie" 1927, no. 176.

${ }_{52}$ M. Skrudlik, Zamachy..., op. cit., pp. 13-16.

53 A. Huszno, Polski Kościól Narodowy..., op. cit., p. 15, 17; M. Skrudlik, Zamachy..., op. cit., pp. 102-104.

54 W. Mroziński, „H” - jak Huszno (1-2) [“H” - for Huszno (1-2)], “Kurier Związkowy” 2003, no. 164,166 . In the first case, it related to Zacharjasiewicz, who, according to Huszno, was running a "divorce factory"; in the second case, to Pietruszka. M. Skrudlik, Zamachy..., op. cit., pp. 21-25, $103-105$.

55 W. Mroziński, "H”-jak Huszno..., op. cit. 
in Warsaw, taking the place of Father Wójec, who had faced disciplinary action. ${ }^{56} \mathrm{He}$ developed a spreading form of cancer, to which he finally succumbed on 4 June 1939. The following day, a brief notice appeared in the newspaper "Polska Zachodnia": "Father Andrzej Huszno, the former parish priest of the Orthodox-National Church, but recently converted to Catholicism, passed away at 2pm on Sunday in Dąbrowa Górnicza." ${ }^{57}$ Ten thousand people attended the funeral of the preacher from Dąbrowa.

\section{Messianism}

In creating the doctrine of his Church, Huszno developed his own version of Protochronism, ${ }^{58}$ rooted in the Polish Romantic messianic tradition. ${ }^{59}$ In the historiosophic vision of Huszno, "the peoples of Europe and Asia are the descendants of the twelve tribes of Israel, who accepted God's Truth in the old world," echo (perhaps unconscious) of the tenets of Anglo-Israelism. ${ }^{61}$ The Slavs, especially the Poles, played a special role amongst these peoples: "The Lechites or the Lechvites are this royal-priestly type, this chosen nation, which is the first guardian of the Word of God." ${ }^{62}$ Huszno tried to prove, using pseudo-linguistic arguments in the style of Father Wojciech Dembołęcki, ${ }^{63}$ that prehistoric Poland was identical to biblical Palestine: "Pales Tyn" was supposed to mean "Polish garden." ${ }^{64}$ Babel was Wawel

${ }^{56}$ Przykre konsekwencje [Unpleasant Consequences], "Goniec Częstochowski” 1937, no. 288.

57 Zmart ks. Andrzej Huszno [Father Andrzej Huszno has Died], "Polska Zachodnia" 1939, 5 June. A precise description of his last moments can be found in the article Umart jako katolik [He Died a Catholic], "Cuda i Łaski Boże" 2007, no. 11.

${ }^{58}$ I use this term after László-Attila Hubbes, who defined it as follows: "theories which posit a primordial and uninterrupted ethnic identity and which unnaturally exaggerate and sanctify its history, claiming that it preceded other nations in time, importance and achievements." L.-A. Hubbes, Romanian ethno-paganism: discourses of nationalistic religion in virtual space [in:] Modern Pagan and Native Faith Movements in Central and Eastern Europe, K. Aitamurto, S. Simpson (eds.), Durham 2013, p. 215.

59 E.g. M. Stach, Gtos czytelnika [A Reader's Voice], GZ 1925, no. 12; Powstań Ludu Polski! [People of Poland, Arise!], GZ 1925, no. 12.

${ }^{60}$ Tajemnica Polski [The Mystery of Poland], GZ 1925, no. 7.

${ }^{61}$ A. Peck, $W$ poszukiwaniu tożsamości. Rasizm $w$ amerykańskich koncepcjach religijnych [In Search of Identity: Racism in American Religious Concepts], Kraków 2007, pp. 91-112; N. Rogacki [R. Nogacki], Anglo-izraelityzm czyli rasowa apokalipsa [Anglo-Israelism or the Racial Apocalypse], "Fronda" 1999, no. 15-16.

${ }^{62}$ Hymn P.K.K. Narodowego [Hymn of the PKKN], GZ 1925, no. 9.

${ }^{63}$ See M. Bauer, Nad „Przewagami elearów polskich” Wojciecha Dembołęckiego. O apologetycznym pamiętniku $z$ walk lisowczyków w krajach monarchii habsburskiej podczas pierwszych lat wojny trzydziestoletniej [On "The Advantages of Polish Elears" by Wojciech Dembołęcki. On the Apologetic Memoir of the Battles of the Lisowczycy in Countries of the Habsburg Monarchy during the First Years of the Thirty Year War], "Napis" 2005, series XI. Wywód jedynowłasnego państwa świata ["The Lineage of a Sovereign State of the World"] available in the digital library POLONA, https://polona.pl/ item/81818/2/ [access: 16.03.2017].

${ }^{64}$ Boże Narodzenie: co znaczy, kiedy byto i gdzie? (cont.) [Christmas: What Does it Mean, When Was it, and Where? (cont.)], GZ 1925, no. 6. 
(Waw El = "I saw God") ${ }^{65}$ Bethlehem meant "Bet lehiw," i.e. the House of Poles, and Barsaba denoted Warszawa (Warsaw) ${ }^{66}$ The holy Indian language Pali was of course the Polish language. ${ }^{67}$

In this context, it will not surprise us that in the opinion of Huszno "the origin of his name [Jesus's name] should be sought not in Jewish Palestine, [...] but in old Slavonism." ${ }^{68}$ As he sought to demonstrate, the old Slavs worshipped Jesus Christ under the name of Jesse Lado. ${ }^{69}$ Of course, this was not the historical Jesus from Roman times, but the real Christ, identified with Rama (this theme will be further elaborated on later) - "the great initiate of the peoples of the Aryan race," a druid who had rebelled against his caste, "who had divine enlightenment" and spoke out against "sensual cults."70 Having identified the pagan beliefs of the Slavs with "authentic" Christianity, Huszno could claim that "Christianity is our native Polish faith, only warped by the princes of the Roman Church." 71 The symbol of this "ancient [prehistoric] Polish-Catholic Church" was to be the oak, and the White Eagle was "the emblem of Christ himself." 72 The role of John the Baptist was played by Piast Kołodziej, announcing the coming of a new Rama, who had just been born on Polish soil. ${ }^{73}$

The Huszno heresy was strongly saturated with Slavic-pagan elements (or at least stylised as such). Admitting that it shared "the faith of our bards" in "prehistoric Slavs," 74 the PKKN declared "belief in the ancient Polish faith," which "Judeo-Christianity" is younger than..$^{75}$ The "Głos Ziemowida" columnist drew conclusions about the moral superiority of Slav paganism, claiming that "if not for Rome and Germany, Poland [...] would be a union of the free with the free, equals with equals, governed by councils of elders, observing Światowid's law." " Neo-pagan fascinations even manifested themselves in the applied terminology: "chram," "katyna Ziemowida" (Old Slavonic names for pagan temples). ${ }^{77}$

In accordance with the principle of cyclicality ("what once was, $[\ldots]$ is now" $" 78$ ), "the divine mission of Poland" was still valid. ${ }^{79}$ "The dogmatic theses of the Polish

${ }^{65}$ Chrystus Rzymianinem [Christ the Roman], GZ 1925, no. 15.

${ }^{66}$ Tajemnica Polski, GZ 1925, no. 7. Moreover, Cyrena - as the stronghold of the Siren (Polish: syrena - a mermaid is the emblem of the city of Warsaw) - was also supposed to be Warsaw. Bozie Narodzenie: co znaczy, kiedy było i gdzie? (cont.), GZ 1925, no 5. The Mermaid, as interpreted by Huszno, is the symbol of God-Man meaning "the new King-Spirit." Tajemnica Polski, GZ 1925, no. 7.

${ }^{67}$ Kto to byt Rama? [Who was Rama?], GZ 1925, no. 18.

${ }_{68}$ Vid Indra, Nowy Rok [New Year], GZ 1925, no. 3.

${ }^{69}$ Ibidem.

${ }^{70}$ Kto to byt Rama?, GZ 1925, no. 18.

71 Tajemnica Polski, GZ 1925, no. 7.

72 Hymn P.K.K. Narodowego, GZ 1925, no. 9.

${ }^{73}$ Kto to byt Rama?, GZ 1925, no. 18.

${ }^{74}$ Tajemnica Polski, GZ 1925, no. 7.

75 Co to jest „Gtos Ziemowida”? [What is Gtos Ziemowida?], GZ 1925, no. 24.

76 Wspótczesne pogaństwo [Contemporary Paganism], GZ 1925, no. 17.

${ }^{77}$ Pasterka w nowym Betleemie [Christmas Eve Service in the New Bethlehem], GZ 1925, no. 3; Hymn P.K.K. Narodowego, GZ 1925, no. 9.

${ }^{78}$ Boże Narodzenie: co znaczy, kiedy było i gdzie? (cont.), GZ 1925, no. 6.

79 Tajemnica Polski, GZ 1925, no. 7. 
National Church" stated that "the Polish nation [...] has been chosen by God as the guardian of the idea of the Kingdom of God on earth. He is that nation, to which [...] at the end of each of the old worlds [...] God sends his Angel." ${ }^{80}$ It was Poles who were supposed to bring salvation to the world by leading humanity into the Kingdom of God. ${ }^{81}$ "We, Poles from the Spirit," wrote "Głos Ziemowida," "are that real Israel, i.e. children of the Truth of God. Our Homeland - Poland - is the real Poale-Stan (i.e. Palestine), the Holy Land. The chosen among the Poles are called to be guardians of the God-Truth and carry this truth to the ends of the earth." $\$ 2$ Poland, according to this concept, became the "mother of all nations of the world." 83

The PKKN's messianism was clearly moving towards nationalism. ${ }^{84}$ "There is only one Truth, but each Nation traces its own path on the way to this Truth," we read in "Głos Ziemowida." ${ }^{\prime 5}$ From this it was concluded that it was necessary to cre-

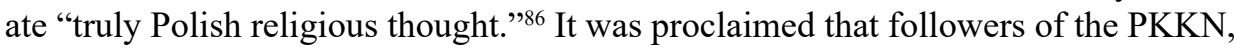
"being Poles by blood, yearn to be [Poles] in spirit." "[Y "[] our Polish earth is your Jerusalem, your Rome, Your Babel," cried Huszno. ${ }^{88 ~ " G ł o s ~ Z i e m o w i d a " ~ e m p h a s i s e d ~}$ that "there is only one truly Polish Church, and that is our Church [...]. Why? Because only we believe in a Polish Christ, in Poland - as the Homeland of Christ and the cradle of His Church. We do not recognise any alien, non-Polish, foreign control over us. We don't have any of those foreign gods, because we believe that our Polish Jesse Lado, in other words Jesus Christ, is the God of all peoples." ${ }^{89}$ The followers of Hodur (founder of the PNKK) were reproached for the fact that the apostles of the PNKK were foreigners: Hus, Calvin, Luther, and Darwin. ${ }^{90}$ This stance also had anti-Semitic implications. "[W]e believe in [...] Christ the Roman, and not a little Jew $[\ldots]$ with sidelocks," announced "Głos Ziemowida" proudly. ${ }^{91}$ Other branches of Christianity were criticised for their "Judeo-Roman [...] foundations," "not [...] Polish, but Jewish messianism," "the messianic mission [...] of sidelocked Talmudists" and "'the Master from Nazareth' of Jewish nationality."

${ }^{80}$ Tezy dogmatyczne Polskiego Kościoła Narodowego [Dogmatic Theses of the Polish National Church], GZ 1925, no. 12.

${ }^{81}$ Tajemnica Polski, GZ 1925, no. 7. See also: Od Redakcji słowo wstepne [Foreword by the Editorial Board], GZ 1924, no. 1; Co to jest „, Głos Ziemowida”?, GZ 1925, no. 24; Główne zasady PolskoKatolickiego Kościoła Narodowego w Dąbrowie Górn[iczej], GZ 1925, no. 12.

${ }^{82}$ Ile jest kościołów polskich? [How Many Polish Churches are there?], GZ 1926, no. 11.

83 V. Indra, Michat Archaniol [Archangel Michael], GZ 1925, no. 22.

${ }^{84}$ This was even manifested in linguistic purism, requiring use of the word wzierstwo [Huszno's neologism] instead of "contemplation." P. Włast, "Prawda polska" ["Polish Truth"], GZ 1925, no. 11.

85 Ibidem.

${ }^{86}$ Z Biura Głównego Zarządu Zjednoczonych Polskich Kościołów w Ameryce [From the Office of the Main Board of the United Polish Churches in America], GZ 1924, no. 1.

${ }^{87}$ Czy wolno być Polakiem? [Is it Permitted to Be a Pole?], GZ 1925, no. 17.

${ }^{88}$ Bóg się rodzi! [God is Born!], GZ 1924, no. 2.

89 Ile jest kościołów polskich?, GZ 1926, no. 11.

90 [A.] Huszno, Skąd nagle żądanie tączności?, GZ 1925, no. 9.

${ }^{91}$ Chrystus Rzymianinem, GZ 1925, no. 15.

92 [A.] Huszno, Skąd nagle żądanie tączności?, GZ 1925, no. 9. 
A logical consequence of the thesis on the necessity of national religious thought was the idea of a national Church. "We, as a free nation $[\ldots]$ have the right $[\ldots]$ to create $[\ldots]$ a Church $[\ldots]$ that is independent from Rome, in which prayers to God will be recited in Polish," wrote Władysław Nowak. ${ }^{93}$ Models for such a Church were sought in Polish history - in the Cyrillo-Methodian diocese in Krakow in the ninth century, in the concepts of Jan Ostroróg, who in 1460 recommended "breaking off $[\ldots]$ all relations with this association of Italo-German universalism" that is the Roman Catholic Church..$^{94}$ Inspiration also came from contemporary foreign models - from Czechoslovakia and Mexico. ${ }^{95}$

However, the PKKN's messianism did not exhibit the xenophobic ethnocentrism that was characteristic of, for example, German national religious movements. ${ }^{96}$ Huszno emphasised that the "concept of the nation [...] has spiritual and not ethnographic significance," which is why "a Church that is truly God's is national-universal, but nationality [...] should be understood in the messianic sense, that through one so-called chosen nation, all others receive the light of faith." ${ }^{97}$ The task of Polish messianism was "to reconcile all the Churches and Nations of the whole world in the unity of God's Truth" in the spirit of traditional Polish tolerance..$^{98}$ "Being national by virtue of its Polish messianism, it [the PKKN] is, however, a long way from tribal nationalism and chauvinism," assured "Głos Ziemowida." "The main principles" of the Huszno Church were that the PKKN "is not a Church of a political or national Poland, but a spiritual, ideal Poland," which is why they allowed foreigners to belong. ${ }^{100}$ "We will proclaim peace to people of goodwill. And not only to poles [sic], but to other nations," we read in the PKKN periodical. ${ }^{101}$ At the same time it was warned that "[n]ot all Poles will be worthy of this great grace" (i.e. salvation in the PKKN). ${ }^{102}$

93 W. Nowak, Księdzu Ziemniakowi [To Father Ziemniak], GZ 1925, no. 19. At the same time, Huszno emphasised that religious union of Poles, Belarusians and Ukrainians within a single state Church would remove national conflicts. A. Huszno, Polski Kościól Narodowy..., op. cit., pp. 3-4.

94 A. Huszno, Polski Kościól Narodowy..., op. cit., pp. 6, 8-9; Stach, Czasy się powtarzają, GZ 1925, no. 16; W.W., Dawność historyczna naszego wystapienia [The Historical Antiquity of Our Message], GZ 1925, no. 24. Cf. F. Kmietowicz, Kiedy Kraków byt Trzecim Rzymem [When Krakow was the Third Rome], Białystok 1994, passim.

95 P. Włast, Lekcja dla socjalistów w Polsce [A Lesson for Socialists in Poland], GZ 1925, no. 17; Wieści z Babilonu, GZ 1925, no. 22.

${ }^{6}$ Cf. J. Tomasiewicz, Neopoganizm - „religia narodowa” - w koncepcjach niemieckiej skrajnej prawicy (do 1945 r.) [Neopaganism - "the national religion" in conceptions of the German Far Right (until 1945)], "Studia nad Faszyzmem i Zbrodniami Hitlerowskimi" ["Studies on Fascism and Nazi War Crimes"] 2005, vol. XXVIII.

97 [A.] Huszno, Skąd nagle żądanie łączności?, GZ 1925, no. 9. Polish nineteeth-century Romantics perceived messianism similarly, cf. J. Tomasiewicz, Po dwakroć niepokorni. Szkice z dziejów polskiej lewicy patriotycznej [Doubly Defiant. Sketches from the History of the Polish Patriotic Left], Łódź 2014, pp. 21-22.

98 P. Włast, „Prawda polska”, GZ 1925, no. 11.

99 Gtos przyjaciela P.K.K.N. [The Voice of a Friend of the P.K.K.N.], GZ 1925, no. 3.

100 Główne zasady Polsko-Katolickiego Kościoła Narodowego w Dąbrowie Górn[iczej], GZ 1925, no. 12 .

101 Od Redakcji stowo wstępne, GZ 1924, no. 1.

102 Powstań Ludu Polski!, GZ 1925, no. 12. 
This was a sort of reversal of ethnocentric logic: it was not Polishness that was the gateway to the National Church, but the PKKN that was the gateway to (authentic) Polishness; it was not that a Pole became a believer, but that a believer became a Pole.

At the same time, Protochronism - which is unsupported by scientific findings - led Huszno to become interested in parascience (or, if you prefer, "alternative science"). ${ }^{103}$ This is a phenomenon typical of movements that challenge the existing reality. Michael Barkun uses the term "stigmatized knowledge" in this context, and explains that "[a] common denominator between racism, alternative science and paganism is that adherents accept as truth knowledge that is rejected or ridiculed by the institutions of mainstream culture." "In the case of the PKKN, this was manifested both in recognising the historicity of Atlantis and $\mathrm{Mu},{ }^{105}$ and in practising "alternative medicine," i.e. natural medicine. ${ }^{106}$

\section{Religion and politics}

The ties linking the main antagonist of the PKKN - the Roman Catholic Church - with the state apparatus and the political right pushed Huszno to become engaged in politics. Huszno emphasised that "our Church is working class and national,"107 which is why his involvement had a dual - national and social - dimension.

"Głos Ziemowida" criticised Roman Catholicism from a patriotic standpoint: it warned that the concordat "would be ruinous for Poland," 108 and regretted that "Poland [...] is Rome's personal property." 109 But it was not only the Vatican that was the object of the PKKN's nationalistic attacks. The Catholic journalist Mieczysław Skrudlik drew attention to "a specific sort of hyper anti-Semitism" characterising Huszno's followers ${ }^{110}$ - indeed, anti-Semitic accents were not uncommon in "Głos Ziemowida."111

${ }^{103}$ E.g. M. Heindel described successive epochs: Polar, Hyperborean, Lemurian, Atlantic, and Aryan. See M. Heindel, Światopogląd różokrzyżowców. Ezoteryczne chrześsijaństwo przyszłości. Elementarna rozprawa o ewolucji czlowieka w przeszlości, jego obecnej budowie wewnętrznej i osiagnięciu petnego rozwoju w przyszłości [The Rosicrucian Cosmo-Conception. Esoteric Christianity of the Future. An Elementary Treatise Upon Man's Past Evolution, Present Constitution and Future Development], Warsaw 1993, chapter Ewolucja na Ziemi [Evolution on Earth].

${ }^{104}$ Quoted in: M. Gardell, Gods of the Blood: The Pagan Revival and White Separatism, DurhamLondon 2003, p. 339. In the case of the PKKN - functioning in an environment that was very different from that of the USA of the late twentieth century - political extremism had a left-wing character.

${ }_{105}$ Boże Narodzenie: co znaczy, kiedy bylo i gdzie?, GZ 1924, no. 2; Zatopiony kontynent - kolebkq ludzkości [The Sunken Continent - the Cradle of Humanity], GZ 1924, no. 2.

106 There was a regular column devoted to natural medicine in "Głos Ziemowida"; it is also known that Huszno ran an illegal medical practice. W. Nowak, Księdzu Ziemniakowi, GZ 1925, no. 19.

107 1-szy i 3-ci maj [1 and 3 May], GZ 1925, no. 11.

${ }_{108}$ Konkordat..., GZ 1925, no. 10.

109 W. Wojski, Jak Ksiadz Stojałowski zmartwychwstat [How Father Stojałowski Resurrected], GZ 1925, no. 16.

${ }^{110}$ M. Skrudlik, Zamachy..., op. cit., p. 29.

${ }^{111}$ E.g., the accusation that Jews take away Polish girls to sporting houses. Nowa zbrodnia Kaina - to organizacja emigracji polskiej do Francji [Cain's New Crime - the Organisation of Polish Emigration to France], GZ 1925, no. 8. 
The PKKN organ also proclaimed that "Poland is a great thing!,"112 that Poles are a pure Aryan race ${ }^{113}$ who once inhabited territories from Kiev to the Baltic, ${ }^{114}$ praised the strengthening of Polishness in the Kresy (Eastern Borderlands) with the help of military settlement, ${ }^{115}$ propagated the cult of national heroes ("luminous spirits of Poland" such as Bolesław the Generous, Kościuszko, Staszic, and Piłsudski ${ }^{116}$ ), and insisted on maintaining "the independence of our Nation" "117 ("May a Polish government and the Polish nation govern in Poland, and not a French, German or Italian capitalist exploiter" $\left.{ }^{118}\right)$.

At the same time, however, let us reiterate that PKKN nationalism was free from xenophobia. It was stated with pride that "Poland [...] was once ahead of the whole world in very many areas," with principles such as individuality, tolerance, pacifism, and union ("a tendency towards togetherness and harmony") being mentioned. ${ }^{119}$ A "Głos Ziemowida” writer considered that Poland, due to its geographical location, is predestined to take over and develop the cultural achievements of humanity - "that which humanity creates [...] concentrates in us." ${ }^{120}$ The messianic tradition, to which the PKKN wanted to be heirs, imperceptibly transformed nationalism into universalism. In "Democratic Church" Huszno had already foretold the advent of "a Great Union of Peoples, encompassing all nations."121 "Głos Ziemowida" condemned "class, racial and national egoisms," considered that "the division of peoples [...] by artificial borders of countries [...] is already an out-of-date thing,"122 and supported the idea of a United States of Europe, "where each Nation will be only a province of an international union." 123 The leading role in the work of unification of Europe and humankind was to belong, let us not forget, to Poland.

The second pillar of the PKKN programme was strongly emphasised social engagement. ${ }^{124}$ It was proclaimed that "the duty of the clergy is [...] to strive for $[\ldots]$ welfare, flowing from love for our neighbour," 125 because "[w]e cannot have love for God, if we have no love for our neighbour." 126 In accordance with the sanctity of earthly life professed by the followers of Huszno, it was stated that "[b]y the word

112 Tajemnica Polski, GZ 1925, no. 7.

${ }^{113}$ Kto to byt Rama?, GZ 1925, no. 18.

114 Tajemnica Krzyża [The Mystery of the Cross], GZ 1925, no. 9.

115 Wieści z kraju i zagranicy [News from Home and Abroad], GZ 1925, no. 14.

116 A. Huszno, Polski Kościół Narodowy..., op. cit., p. 29; 1-szy i 3-ci maj, GZ 1925, no. 11; P. Włast, Co Polska dała ludzkości? [What Poland has Given to Humanity], GZ 1925, no. 14.

117 P. Włast, $O$ walce międzynarodówek, GZ 1925, no. 20.

118 Nowa zbrodnia Kaina - to organizacja emigracji polskiej do Francji, GZ 1925, no. 8.

119 P. Włast, Co Polska dała ludzkości?, GZ 1925, no. 14; Nasze wydawnictwo, GZ 1925, no. 21.

120 P. Włast, Co Polska ludzkości dać musi?, GZ 1925, no. 18.

121 A. Huszno, Kościót demokratyczny, op. cit., p. 17.

${ }_{122} O$ walce międzynarodówek [On the Struggle of the Political Internationals], GZ 1925, no. 14.

${ }_{123}$ P. Włast, O walce międzynarodówek, GZ 1925, no. 16; idem, O walce międzynarodówek, GZ 1925, no. 19.

124 W. Nałęcz, Praktyczne chrześcijaństwo [Practical Christianity], GZ 1925, no. 19.

${ }^{125}$ Odczyt dla wszystkich $w$ Polsce, GZ 1925, no. 18.

${ }^{126}$ Przygody Ziemowida, GZ 1925, no. 15. 
'salvation,' we mean happiness, liberation from the shackles of bondage of capitalism, ignorance, addiction, laziness, and poverty." 127 Furthermore, religion was supposed to be not an addition to charitable activity, but a fundamental means of social transformation. As early as 1917, Huszno had written: "When humanity understands the teachings of Christ and turns them into actions, then the tyranny of rulers and all socio-national scourges such as militarism and capitalism will disappear; tribal chauvinism and racial hatred will also disappear. Religion will cease to be a bridle and a safety valve in the hands of states or privileged classes, and will become that good, joyous news." 128 The liberation of the people was supposed to take place through Christ and on this Earth. "Głos Ziemowida" was full of revolutionary-apocalyptic prophesies: "the Lord is coming back [...], in order to lift up the wretched and exploited worker and peasant, and to let the merciless rich man go with nothing. The Lord is coming back, to put a stop to the diabolical dances around the golden calf, capital, to put an end to wars and oppression." 129

The PKKN subjected capitalism to merciless criticism. ${ }^{130}$ "Głos Ziemowida" proclaimed that capitalists "had lost faith in the existence of God, [and] [1]oss of faith is accompanied by a desire to exploit [...] the proletariat."131 As a result, "[c]apitalists multiply their fortunes at the cost of workers' health and strength,"132 and the "Polish worker [...] experiences a period of true Egyptian slavery, at the mercy of capitalists." 133 The bourgeois mentality was described by a mocking "capitalist prayer": "I believe in the Golden Calf, the emblem of capitalists throughout the world [...]. I believe in the magic power of the clanging coin [...]. I believe in the triumph of capital over work, strength over the truth, darkness over light and in the eternal kingdom of Satan - the spirit of evil and exploitation." 134

A new social order in which "all property in the country belongs to the whole nation, represented by the government," ${ }^{135}$ was to be an alternative to capitalism. A special role was assigned to workers' self-government and (workers') co-ownership, ${ }^{136}$

127 Kościól a kwestja społeczna, GZ 1924, no. 2.

128 A. Huszno, Syn Człowieczy [Son of Man], Kraków 1917, p. 51.

${ }^{129}$ Adwent nowej ery [Advent of a New Era], GZ 1924, no. 1; see also Co znaczy Niepokalane poczęcie Maryi Panny? [What does the Immaculate Conception of the Virgin Mary Mean?], GZ 1924, no. 1; Kościól a kwestja społeczna, GZ 1924, no. 2; Dola chlebodawcy górnika w Zagłębiu Dąbrowskiem [The Lot of the Miner's Employer in Zagłębie Dąbrowskie], GZ 1925, no. 4; Chrystus zmartwychwstan jest! [Christ is Risen!], GZ 1925, no. 10; Prośba ludu pracującego z okazji Zmartwychwstania Pańskiego [A Request from Working People on the Occasion of the Resurrection], GZ 1925, no. 10.

${ }^{130}$ For example: Apel robotników z Zagłębia Dąbrowskiego do posłów [Appeal of Workers from Zagłębie Dąbrowskie to Senators], GZ 1925, no. 14; Głos bezrobotnego obecnej chwili [The Voice of the Unemployed at the Current Moment], GZ 1925, no. 22; S. Janiszewski, List w sprawie bezrobotnych [Letter about the Unemployed], GZ 1925, no. 24.

131 W.N., Odpowiedź księdzu Ziemniakowi, GZ 1925, no. 15.

132 Kto nas wyzwoli?, GZ 1925, no. 17.

133 Czy będa z nich ludzie? [Will They be Good People?], GZ 1925, no. 12.

134 Satyr, Pacierz „pobożnej” „Iskry” i Spótki [The Prayer of “the Pious”, "Iskra” and the Company], GZ 1925, no. 11.

135 Kto nas wyzwoli?, GZ 1925, no. 17.

${ }^{136}$ Czy będą z nich ludzie?, GZ 1925, no. 12. 
because only they "[w]ho work [...] should have the right to title deeds." 137 The short-term programme [of the PKKN] was more modest and directly linked with the interests of the PKKN miners' social base: strict state control over mining, regulation of pay by making a supervisor's wages dependent on workers' wages, and reduction of clerical staff. ${ }^{138}$ However, there was a sceptical attitude to the main demand from the countryside, i.e. agricultural land reform - dividing into plots (parcelling) was criticised as an irrational fragmentation of property; control of agriculture by the state and agricultural bodies was proposed instead. ${ }^{139}$

This social radicalism conflicted with the concept of the wandering of souls proclaimed by the PKKN, the socially conservative implications of which are not difficult to discern - after all, people deserved their lot due to previous lives (incarnations). "Bad people are placed by their own conscience in such conditions that in their new life they occupy the sins of the previous life," 140 wrote Huszno, elsewhere adding: "Poor people [...] these are the souls of sinners suffering in the purgatory of life." 141 However, he bypassed the conflict caused by the above concept, focusing on the immediate social programme, since his proletarian faithful expected this.

Social-radicalism, anti-clericalism, and patriotism - all this pushed the PKKN towards the Polish Socialist Party. Already in 1919, the socialist press had stood in defence of the victimised Huszno. ${ }^{142}$ Later that cooperation deepened. Huszno, as was written, "fraternises with the socialists, defends workers, and does not respect capitalists," 143 which in practice translated into lectures by Huszno for members of the Polish Socialist Party ${ }^{144}$ and appeals to vote for this party. ${ }^{145}$ The socialists' programme was, in the opinion of "Głos Ziemowida," "legal, sober and possible to achieve in our conditions." 146 However, the PKKN cut itself off from the Bolshevik revolution, emphasising that "a political revolution without a spiritual revolution will not make us happy." 147 Communism was compared to "the Red Sea," which

${ }^{137}$ Kto nas wyzwoli?, GZ 1925, no. 17.

${ }^{138}$ Czy będa z nich ludzie?, GZ 1925, no. 12.

139 W.W., Poradnik rolniczy [Agricultural Guide], GZ 1925, no. 14. Although there were different opinions. W. Wojski, Poradnik rolniczy, GZ 1925, no. 19.

${ }^{140}$ Młody kaptan, który zmartwychwstaje jako mloda dziewczyna [A Young Priest Who is Resurrected as a Young Girl], GZ 1925, no. 7.

${ }^{141}$ O życiu poza grobem [On Life beyond the Grave], GZ 1925, no. 23.

${ }^{142}$ Sprawy Kościoła, "Przegląd Powszechny" 1919, vol. 141-142, p. 230.

${ }^{143}$ Bolesne żale ks. Ziemniaka i przechrzcianki ,Iskry” [The Painful Sorrows of Father Ziemniak and the Converts of "Iskra"], GZ 1925, no. 19.

${ }_{144}$ Przygody Ziemowida, GZ 1925, no. 15; Odczyt dla wszystkich w Polsce [A Reading for Everyone in Poland], GZ 1925, no. 18.

${ }^{145}$ Do mieszkańców miasta Dąbrowy Górniczej [To the Inhabitants of Dąbrowa Górnicza], GZ 1925, no. 10; Monarchiści i P.K.K.N. [Monarchists and P.K.K.N.], GZ 1925, no. 19; O upadku godności obywatelskiej $w$ Polsce [On the Loss of Citizens' Dignity in Poland], GZ 1925, no. 23.

146 1-szy i 3-ci maj, GZ 1925, no. 11.

${ }^{147}$ Kto nas wyzwoli?, GZ 1925, no. 17. 
constituted "God's whip for the Pharaoh" and "the bowl of God's anger;" however, "[i]t was not the goal of the people of Israel, [...] but Mount Sinai."148

However, this did not mean full identification with the Marxist ideology of the Polish Socialist Party. "Głos Ziemowida" called on socialists to review their materialistic stance, ${ }^{149}$ to recognise religion as the foundation of social reforms, ${ }^{150}$ and establish a national Church. ${ }^{151}$ Analysis of Huszno's political projects shows even deeper, veritably insurmountable differences from the socialist programme. Whereas the Polish Socialist Party unquestionably had its basis in parliamentary democracy, "Głos Ziemowida" remained very critical of the "Sejmocracy" (parliamentary hegemony). The periodical proclaimed that "[t]oday party loudmouths rule"152 and the Sejm is "miserable and infirm in its entirety." "153 It was not incidental, but fundamental criticism - according to "Głos," "[d] emocratism is an artificial slogan [...] people are born unequal, different."154 The PKKN was inclined to accept only "Polish aristocratic democratism."155

What should the ideal political system be like, according to Huszno? Perhaps it could best be described by the term "theodemocratic." Huszno wrote that the "Sovereign above sovereigns" is God, ${ }^{156}$ but "[a]11 just authority originates from the will of the nation," since "[t]he will of a conscious nation [...] is the will of God."157 However, this did not just mean religious justification of democracy (as in Giuseppe Mazzini's concept of "Dio e popolo" ${ }^{158}$ ). Assuming that "religion is a social matter" and not a private one, ${ }^{159}$ Huszno proclaimed the unity of state power and religion. "Power is a sacred thing, when it rests in the hands of saints," and, as he foretold "the time is cloze [sic], when saints [...] will hold power [...]. Then Paradise will return to earth." 160 Although the immediate programme of the PKKN demanded the separation of the (Roman Catholic) Church from the state, Huszno made it plain that in the future "spiritual and secular power will cooperate $[. .$.$] for the realisation of the$ Kingdom of God on earth" and ultimately "these two powers will merge into one,"161

148 Robotniku, w Bogu cała nadzieja twoja! [Worker, All Your Hope in God!], GZ 1925, no. 6. Anticommunism resulted in Father Ignacy Skorupka being one of the very few Catholic priests with a good reputation - precisely because of the struggle against the Bolsheviks. Wieści z Babilonu, GZ 1925, no. 22.

149 Wojski, Walka Czechów z Rzymem Papieskim [The Struggle of the Czechs with Papal Rome], GZ 1925, no. 21.

150 Socjalista [Socialist], Czy religja to rzecz prywatna? [Is Religion a Private Matter?], GZ 1925, no. 22 .

151 P. Włast, Lekcja dla socjalistów w Polsce [A Lesson for Socialists in Poland], GZ 1925, no. 17.

152 V. Indra, O władzy [On Power], GZ 1925, no. 12.

153 W. Wojski, Poradnik rolniczy, GZ 1925, no. 19.

154 P. Włast, O walce międzynarodówek, GZ 1925, no. 15.

155 P. Włast, Co Polska ludzkości dać musi? [What Must Poland Give Humanity?], GZ 1925, no. 18.

156 Robotniku, w Bogu cała nadzieja twoja!, GZ 1925, no. 6.

157 A. Huszno, Kościół demokratyczny, op. cit., pp. 8-9.

158 J. Ugniewska-Dobrzańska, Giuseppe Mazzini - historia jako narodowa terapia [Giuseppe Mazzine - History as National Therapy], Wrocław 1986, p. 95.

159 W. Nałęcz, Polski Kościół Prawosławny [The Polish Orthodox Church], GZ 1925, no. 21.

160 V. Indra, O władzy, GZ 1925, no. 12.

161 Jeden z wielu, Kościót a Sprawa Społeczna [One of Many, Church and Social Cause], GZ 1925, no. 21. 
into a uniform priestly-royal power. ${ }^{162}$ "And it will come to pass that the church will be the state, and the state will be the church." 163 However, Huszno warned that: "Our world [...] will only be heaven for those who accept the Truth revealed by the P.K.K.N. [...], but it will remain hell for those who despise it." 164 This can be considered an unintentional prophetic anticipation of communist totalitarianism.

\section{New Age precursor or last romantic?}

Huszno's religious system can be perceived as an attempt to implement foreign esoteric thought into Poland, but also as one of the last efflorescences of the Polish Romantic tradition. Between the wars, this tradition experienced a renaissance, represented by the Piłsudskiites ${ }^{165}$ or the synarchists on the political level, ${ }^{166}$ and on the philosophical level by, for example, the Instytut Mesjanistyczny (Messianic Institute). ${ }^{167}$ Andrzej Walicki mentioned the following among the features of Romantic thought:

an apologia for charismatic leadership, the concept of progress as a 'chain of revelations'; [...] the postulate of 'the rehabilitation of materiality' express[ing] an aspiration - typical of millenarianism - towards 'terrestrialisation' of the idea of salvation; [...] combining the idea of collective salvation with the idea of progressive reincarnation, indicating the path to individual salvation on earth; the thought that the mission of Christ was to liberate man as an individual - but only spiritually; now, however, the time of social liberation and establishing the material well-being of humankind on earth is approaching. ${ }^{168}$

All these elements can also be found in the Polish-Catholic National Church.

Translated by George Lisowski

162 A. Huszno, Kościót demokratyczny, op. cit., p. 15; cf. Odczyt dla wszystkich w Polsce, GZ 1925, no. 18; A. Huszno, Polski Kościół Narodowy..., op. cit., p. 30.

${ }_{163}$ V. Indra, O wtadzy, GZ 1925, no. 12.

164 Tezy dogmatyczne Polskiego Kościoła Narodowego, GZ 1925, no. 12.

${ }^{165}$ L. Kamiński, Romantyzm a ideologia. Główne ugrupowania polityczne Drugiej Rzeczypospolitej wobec tradycji romantycznej [Romanticism and Ideology. The Main Political Groups of the Second Republic vis-à-vis the Romantic Tradition], Wrocław-Warszawa-Kraków-Gdańsk 1980, pp. 22-23, 33, $39,53,55$.

166 Polish political movement based on the Messianist philosophy of Józef Maria Hoene-Wroński (1776-1853), established by Włodzimierz Tarło-Maziński in 1924. J. Tomasiewicz, Naprawa ..., op. cit., pp. 364-368.

167 R. Łętocha, ,, Oportet vos nasci denuo”. Myśl spoleczno-polityczna Jerzego Brauna [“Oportet vos nasci denuo": The Socio-Political Thought of Jerzy Braun], Kraków 2006, pp. 23-24, 84-99.

168 A. Walicki, Millenaryzm i mesjanizm religijny a romantyczny mesjanizm polski. Zarys problematyki [Religious Millenarianism and Messianism vis-à-vis Polish Romantic Messianism: An Outline of the Issues], "Pamiętnik Literacki" 1971, no. 4. 


\section{References}

\section{Primary sources}

"Głos Ziemowida" 1924-1925.

"Goniec Częstochowski" 1937.

"Hasło Łódzkie" 1928.

Huszno A., Kościót demokratyczny, Kraków 1919.

Huszno A., Polski Kościót Narodowy, jego historja, cel i zasady, Dąbrowa Górnicza 1928.

Huszno A., Syn Człowieczy, Kraków 1917.

"Jednodniówka Maryawicka" 1926.

"Polska Zachodnia" 1939.

"Przegląd Powszechny" 1919-1926.

Skrudlik M., Zamachy na Kościót Katolicki w Polsce, Warszawa 1928.

"Słowo Pomorskie" 1927.

\section{Secondary sources}

Bauer M., Nad „Przewagami elearów polskich” Wojciecha Dembotęckiego. O apologetycznym pamiętniku z walk lisowczyków w krajach monarchii habsburskiej podczas pierwszych lat wojny trzydziestoletniej, "Napis" 2005, seria XI.

Chylak K., Polski Narodowy Kościót Katolicki w Łodzi (1918-1951), "Rocznik Łódzki” 2010, Vol. LVII, pp. 89-102.

Ciepiela B., Historia parafii Matki Bożej Nieustającej Pomocy w Strzyżowicach, http://strzyzowice.pl/index.php?name=Sections\&req=viewarticle\&artid=28\&page=1 [access: 19.02.2007].

Gardell M., Gods of the Blood: The Pagan Revival and White Separatism, Durham-London 2003.

Gazda G., Dwudziestolecie międzywojenne. Stownik literatury polskiej, Gdańsk 2008.

Grześczyk A., Z dziejów ludowej herezji-Polski Narodowy Kościót Katolicki, "Ha!art” 2016, no. 1, pp. 34-38.

Heindel M., Światopoglą różokrzyżowców. Ezoteryczne chrześcijaństwo przyszłości. Elementarna rozprawa o ewolucji człowieka w przeszłości, jego obecnej budowie wewnętrznej i osiagnięciu petnego rozwoju w przyszłości, Warszawa 1993.

Jorsz S., Historyczne znaczenie misji wschodniej jezuitów w Albertynie, "Roczniki Teologiczne" 2006-2007, vol. LIII-LIV, no. 7, pp. 145-152.

Kamiński L., Romantyzm a ideologia. Główne ugrupowania polityczne Drugiej Rzeczypospolitej wobec tradycji romantycznej, Wrocław-Warszawa-Kraków-Gdańsk 1980.

Kmietowicz F., Kiedy Kraków był Trzecim Rzymem, Białystok 1994.

Łętocha R., ,, Oportet vos nasci denuo”. Myśl społeczno-polityczna Jerzego Brauna, Kraków 2006.

Mirończuk J., Polski Narodowy Kościół Katolicki w Łomży - powstanie, oddziaływanie, zanik (1928-1944), "Studia Łomżyńskie" 2009, vol. XX, pp. 31-49.

Modern Pagan and Native Faith Movements in Central and Eastern Europe, K. Aitamurto, S. Simpson (eds.), Durham 2013.

Mroziński W., ,H”- jak Huszno (1-2), “Kurier Związkowy” 2003, no. 164, p. 166.

Pastuszewski S., Karta prawosławna $w$ dziejach Bydgoszczy [in:] Kalendarz Bydgoski na Rok 1987, Bydgoszcz 1986, pp. 29-35.

Peck A., W poszukiwaniu tożsamości. Rasizm w amerykańskich koncepcjach religijnych, Kraków 2007.

Rogacki N. [Nogacki R.], Anglo-izraelityzm czyli rasowa apokalipsa, "Fronda" 1999, no. 15-16, pp. 241-246.

Tomasiewicz J., Naprawa czy zniszczenie demokracji? Tendencje autorytarne i profaszystowskie w polskiej myśli politycznej (1921-1935), Katowice 2012. 
Tomasiewicz J., Neopoganizm - „religia narodowa” - w koncepcjach niemieckiej skrajnej prawicy (do 1945 r.), "Studia nad Faszyzmem i Zbrodniami Hitlerowskimi" 2005, vol. XXVIII, pp. 103-120.

Tomasiewicz J., Po dwakroć niepokorni. Szkice z dziejów polskiej lewicy patriotycznej, Łódź 2014.

Tomasiewicz J., Religia, naród i państwo w neopogańskiej filozofii Jana Stachniuka, "Nomos" 1999, no. 24-25, pp. 63-78.

Ugniewska-Dobrzańska J., Giuseppe Mazzini - historia jako narodowa terapia, Wrocław 1986.

Umart jako katolik, "Cuda i Łaski Boże” 2007, no. 11.

Walicki A., Millenaryzm i mesjanizm religijny a romantyczny mesjanizm polski. Zarys problematyki, "Pamiętnik Literacki" 1971, no. 4, pp. 23-46.

Werschler I., Z dziejów obozu belwederskiego. Tadeusz Hołówko - życie i działalność, Warszawa 1984. 